\title{
Heavy Metal Levels on Largemouth Bass (Micropterus salmoides Lacépède, 1802) from Tagus River Basin
}

\author{
António Moitinho Rodrigues ${ }^{1,2 *}$ and Abel Veloso² \\ ${ }^{1}$ School of Agriculture, Polytechnic Institute of Castelo Branco, Portugal \\ ${ }^{2}$ CERNAS - Research Center for Natural Resources,Environment and Society (FCT project UID/AMB/00681/2013) - Polytechnic Institute of Castelo \\ Branco, 6000-084 Castelo Branco, Portugal
}

Submission: January 22, 2018; Published: March 12, 2018

*Corresponding author: António Moitinho Rodrigues, School of Agriculture, Polytechnic Institute of Castelo Branco, Qt.ㄹ Sr.․․ Mércules, 6001-909, Castelo Branco, Portugal, Email: amrodrig@ipcb.pt

\section{Introduction}

The Tagus River is the longest waterway in the Iberian Peninsula $(1,007 \mathrm{~km})$ with source in Albarracín mountain- Spain and mouth in a wide estuary near Lisbon - Portugal. Throughout $32 \%$ of its waterway Tagus River influences the Portuguese territory with several irrigation dams and hydroelectric power plants. For decades, this river has received environmental pollutants from increased activities in industrial, domestic and agricultural systems, and also from a Spanish nuclear power plant that is 37 years old. This nuclear power plant is about to $100 \mathrm{~km}$ far from the Portuguese border. For all those reasons it is very important to know the level of contamination of aquatic animals living in Tagus River. In many cases the toxicity caused by heavy metals is sublethal. Therefore, the animals can survive long enough to accumulate those metals and transfer them along the food chain.

Historically, fish consumption per capita in Portugal has been very high. In 2013 Portugal had the highest per capita fish consumption (53.8kg/capita/year) among the 28 European Countries. After Iceland and Japan, Portugal is the country with highest fish consumption per capita in the World [1]. Although the consumption of freshwater fish are lower than the consumption of marine fish, freshwater fish are very important in some interior areas of Portugal. It represents $6 \%$ of the total fish consumption [2]. In some Portuguese areas crossed by Tagus River largemouth bass (Micropterus salmoides Lacépède, 1802) (LB) is the most popular freshwater sport's fish. This fish with high gastronomic interest was introduced from USA in 1952 [3]. It is very important in regional cuisine and it is much appreciated due to their exquisite flavor. An apex predator like LB has high potential to bioaccumulate high levels of contaminants due to its trophic position [4]. LB could be used as a bioindicator. It is particularly good integrator of environmental stress because it is at the top of the aquatic food chain.

\section{Heavy Metals}

Heavy metals are one of the mostimportant forms of pollution in the aquatic environment. The first outbreak of poisoning in humans caused by consumption of fish contaminated with heavy metals was observed in Japan in 1953, during which more than 43 Minamata Bay residents died and more than 700 suffered permanent disabilities after the consumption of fish contaminated by industrial sewage of a factory [5]. The common heavy metals found in fish muscle tissue are cadmium (Cd), chromium (Cr), copper ( $\mathrm{Cu}$ ), iron (Fe), mercury ( $\mathrm{Hg})$, manganese $(\mathrm{Mn})$, lead $(\mathrm{Pb})$ and zinc $(\mathrm{Zn}) . \mathrm{Cu}, \mathrm{Fe}, \mathrm{Mn}$ and $\mathrm{Zn}$ might be essential metals as they play important roles in fish biological systems, while $\mathrm{Cd}, \mathrm{Cr}, \mathrm{Hg}$ and $\mathrm{Pb}$ are toxic metals. However essential metals can have toxic and adverse effects at high concentrations [6]. Fishes may accumulate large amounts of metals from the water and sediments, mainly fish species on the top of trophic chain. If they are highly consumed by humans it is important to determine the level of heavy metals on the edible part of this fishes in order to evaluate the possible risk for human health.

Some studies have been done to determine heavy metals concentration on LB collected from Tagus River basin near the Portuguese border $[7,8]$. The authors have studied the heavy metal concentration on LB muscle tissue from Tagus River (TR) and from Tagus River basin irrigation reservoirs (IR, IR1 and IR2) (Table 1). It is very important to know if those fishes are safe for human consumption.

With an Atomic Spectrophotometer Belo et al. [6] found an average of $\mathrm{Cd} 0.03$ mg. $\mathrm{kg}^{-1} \mathrm{ww}$ and $\mathrm{Pb} 0.63 \mathrm{mg} . \mathrm{kg}^{-1}$ ww (IR1 and IR2), and Rodrigues et al. [7] found a concentration of Cd, $\mathrm{Cr}$, and $\mathrm{Pb}$ lower than the Inductively Coupled Plasma-Optical Emission Spectrometry (ICP-OES) limit of quantification $(0.05$, 0.03 and $0.2 \mathrm{mg} . \mathrm{kg}^{-1} \mathrm{ww}$ ) respectively in TR and IR largemouth bass (Table 1). In both studies $\mathrm{Cu}, \mathrm{Fe}, \mathrm{Hg}, \mathrm{Mn}, \mathrm{Pb}$ and $\mathrm{Zn}$ were 
higher on largemouth bass from irrigation reservoirs than on largemouth bass from Tagus River. Small irrigation reservoirs are closed systems with no hydrodynamic capacity to recycle the diffuse sources of contamination. Excluding $\mathrm{Mn}$ and $\mathrm{Pb}$ from LB IR1 and IR2 all metal concentration were below the maximum limits for a safe human consumption. The LB IR heavy metals concentration obtained by Rodrigues et al. [7] was lower than LB IR heavy metals concentration referred by Belo et al. [8]. This seems to indicate that the contamination of irrigation reservoirs has been declining in the last 10 years. Rodrigues et al. [7]. found a high positive correlation between $\mathrm{Hg}$ muscle concentration and IR LB length $\left(R^{2}=0.887 ; p \leq 0.01\right)$, weight $\left(R^{2}=0.865 ; p \leq 0.01\right)$ and age $\left(R^{2}=0.762 ; p \leq 0.01\right)$. This indicate that apex predators like LB are accumulating greater amount of $\mathrm{Hg}$ the largest and older they became.

Table 1: Metal concentration (mg.kg-1 ww) on the edible part of largemouth bass captured in Tagus River

\begin{tabular}{|c|c|c|c|c|c|c|c|c|}
\hline \multirow{2}{*}{ Elements } & \multirow{2}{*}{$\begin{array}{l}\text { TR(a) } \\
\text { Mean }\end{array}$} & \multirow{2}{*}{$\begin{array}{l}\text { IR(a) } \\
\text { Mean }\end{array}$} & \multirow{2}{*}{ Max } & \multicolumn{2}{|c|}{ IR1(b) } & \multicolumn{2}{|c|}{ IR2(b) } & \multirow{2}{*}{ Max tol } \\
\hline & & & & Mean & Max & Mean & Max & \\
\hline $\mathrm{Cd}$ & $\begin{array}{l}<\mathrm{LOQ} \\
-0.05\end{array}$ & $\begin{array}{l}<\mathrm{LOQ} \\
-0.05\end{array}$ & - & $\begin{array}{r}0.03 \\
\pm 0.01\end{array}$ & 0.06 & $\begin{array}{c}0.03 \\
\pm 0.02\end{array}$ & 0.04 & 0.05 \\
\hline $\mathrm{Cr}$ & $\begin{array}{c}<\text { LOQ } \\
-0.03\end{array}$ & $\begin{array}{l}<\mathrm{LOQ} \\
-0.03\end{array}$ & - & - & - & - & - & 1 \\
\hline $\mathrm{Cr}$ & $\begin{array}{r}0.159 \\
\pm 0.016\end{array}$ & $\begin{array}{r}0.148 \\
\pm 0.017\end{array}$ & $\begin{array}{l}0.181 \\
\text { (TR) }\end{array}$ & $\begin{array}{r}3.23 \\
\pm 0.44\end{array}$ & 4.26 & $\begin{array}{r}2.41 \\
\pm 0.72\end{array}$ & 3.61 & 50 \\
\hline $\mathrm{Fe}$ & $\begin{array}{c}1.45 \\
\pm 0.278\end{array}$ & $\begin{array}{r}1.803 \\
\pm 0.438\end{array}$ & $\begin{array}{c}2.528 \\
\text { (IR) }\end{array}$ & $\begin{array}{r}5.03 \\
\pm 0.38\end{array}$ & 10.8 & $\begin{array}{c}4.9 \\
\pm 0.40\end{array}$ & 3.61 & 50 \\
\hline $\mathrm{Hg}$ & $\begin{array}{r}0.078 \\
\pm 0.018\end{array}$ & $\begin{array}{r}0.223 \\
\pm 0.173\end{array}$ & $\begin{array}{c}0.546 \\
\text { (IR) }\end{array}$ & - & - & - & - & 0.5 \\
\hline $\mathrm{Mn}$ & $\begin{array}{r}0.038 \\
\pm 0.036\end{array}$ & $\begin{array}{r}0.048 \\
\pm 0.033\end{array}$ & $\begin{array}{c}0.096 \\
\text { (IR) }\end{array}$ & $\begin{array}{r}0.58 \\
\pm 0.09\end{array}$ & 0.96 & $\begin{array}{r}0.49 \\
\pm 0.03\end{array}$ & 0.55 & 4 \\
\hline $\mathrm{Pb}$ & $\begin{array}{c}<\text { LOQ } \\
-0.2\end{array}$ & $\begin{array}{c}<\mathrm{LOQ} \\
-0.2\end{array}$ & - & $\begin{array}{r}0.46 \\
\pm 0.20\end{array}$ & 0.47 & $\begin{array}{r}0.63 \\
\pm 0.15\end{array}$ & 0.91 & 0.2 \\
\hline $\mathrm{Zn}$ & $\begin{array}{c}3.76 \\
\pm 0.263\end{array}$ & $\begin{array}{r}1.171 \\
\pm 0.490\end{array}$ & $\begin{array}{c}5.323 \\
\text { (IR) }\end{array}$ & $\begin{array}{r}6.73 \\
\pm 0.23\end{array}$ & 8.51 & $\begin{array}{c}7.0 \\
\pm 0.131\end{array}$ & 7.97 & 100 \\
\hline
\end{tabular}

(TR) (n=9) and in Tagus River basin Irrigation Reservoirs (IR, n=11) (IR1, n=9) (IR2, n=9).

Note: ww - wet weight; LOQ - limit of quantification; max - maximum value found; max tol - maximum tolerable value; (a) Rodrigues et al. (2018); (b) Belo et al. (2007).

\section{Conclusion}

Although IR LB had higher heavy metal levels than LB TR, heavy metal concentrations in largemouth bass muscle tissues collected in Tagus River basin near the border Portugal Spain were below the maximum permissible for a safe human consumption. Nevertheless, a good program of heavy metals control over this fish species should be applied with a certain frequency by authorities to prevent eventual contamination of those ecosystems with negative consequences to human health.

\section{Funding}

Supported by National Funds through FCT - Foundation for Science and Technology, Portugal

\section{References}

1. FAO (2017) Fishery and Aquaculture Country Profiles - The Portuguese Republic.

2. FAO (2013) FAOSTAT.
3. Sanches JC, Rodrigues AM (2011) 0 achigã (Micropterus salmoides), uma espécie com interesse para a pesca desportiva. Agroforum 26: $17-22$.

4. Kumar B, Mukherjee DP, Kumar S, Mishra M, Prakash D, (2011) Bioaccumulation of heavy metals in muscle tissue of fishes from selected aquaculture ponds in east Kolkata wetlands. Annals of Biology Research 2(5): 125-134.

5. Mousavi SL, Moghimi A, Nasimi M (2012) Investigation of pollution level of some heavy metals including cadmium, lead, chromium, and nickel in the flesh of farmed rainbow trout in Sepidan city of Fars province. Journal of American Science 8(7): 140-143.

6. Bat L, Arici E, Urkmez D (2017) Heavy metal levels in the Black Sea sprat (Sprattus sprattus). International Journal of Research in Agriculture and Forestry 4(6): 1-8.

7. Rodrigues AM, Antunes P, Paulo L, Pereira ME and Pinto-de-Andrade L (2018). Metal contaminants in largemouth bass (Micropterus salmoides Lacépède, 1802) from different origins. International Journal of Research in Agriculture and Forestry 5(1): 8-14.

8. Belo AP, Castro VO, Rodrigues AM (2007) Determination of some metalions in the bodies of black-bass (Micropterus salmoides) and tench 
(Tinca tinca), and from water reservoirs close to border of Portugal/ his work is licensed under Creative Commons Attribution 4.0 License DOI: 10.19080/OFOAJ.2018.06.555691
Spain. International Journal of Agriculture and Biology 9(3): 408-411.

\section{Your next submission with Juniper Publishers} will reach you the below assets

- Quality Editorial service

- Swift Peer Review

- Reprints availability

- E-prints Service

- Manuscript Podcast for convenient understanding

- Global attainment for your research

- Manuscript accessibility in different formats

( Pdf, E-pub, Full Text, Audio)

- Unceasing customer service

Track the below URL for one-step submission https://juniperpublishers.com/online-submission.php 